\title{
Small interfering RNA targeting mcl-1 enhances proteasome inhibitor-induced apoptosis in various solid malignant tumors
}

\author{
Wei Zhou ${ }^{1,2}$, Jingzi Hu ${ }^{3}$, Haimei Tang ${ }^{2}$, Da Wang ${ }^{1,2}$, Xuefeng Huang ${ }^{1,2}$, Chao He ${ }^{1,2}$ and Hongbo Zhu ${ }^{1,2^{*}}$
}

\begin{abstract}
Background: Targeting the ubiquitin-proteasome pathway is a promising approach for anticancer strategies. Recently, we found Bik accumulation in cancer cell lines after they were treated with bortezomib. However, recent evidence indicates that proteasome inhibitors may also induce the accumulation of anti-apoptotic Bcl-2 family members. The current study was designed to analyze the levels of several anti-apoptotic members of Bcl-2 family in different human cancer cell lines after they were treated with proteasome inhibitors.

Methods: Different human cancer cell lines were treated with proteasome inhibitors. Western blot were used to investigate the expression of Mcl-1 and activation of mitochondrial apoptotic signaling. Cell viability was investigated using SRB assay, and induction of apoptosis was measured using flow cytometry.
\end{abstract}

Results: We found elevated Mcl-1 level in human colon cancer cell lines DLD1, LOVO, SW620, and HCT116; human ovarian cancer cell line SKOV3; and human lung cancer cell line H1299, but not in human breast cancer cell line MCF7 after they were treated with bortezomib. This dramatic Mcl-1 accumulation was also observed when cells were treated with other two proteasome inhibitors, MG132 and calpain inhibitor I (ALLN). Moreover, our results showed Mcl-1 accumulation was caused by stabilization of the protein against degradation. Reducing Mcl-1 accumulation by Mcl-1 siRNA reduced Mcl-1 accumulation and enhanced proteasome inhibitor-induced cell death and apoptosis, as evidenced by the increased cleavage of caspase-9, caspase-3, and poly (ADP-ribose) polymerase.

Conclusions: Our results showed that it was not only Bik but also Mcl-1 accumulation during the treatment of proteasome inhibitors, and combining proteasome inhibitors with Mcl-1 siRNA would enhance the ultimate anticancer effect suggesting this combination might be a more effective strategy for cancer therapy.

\section{Background}

Proteasome inhibitors represent a new class of agents for cancer therapeutics $[1,2]$. The $26 \mathrm{~S}$ proteasome is a 2 , 000-kDa multimeric cylindrical complex comprising a $20 \mathrm{~S}$ catalytic core and a $19 \mathrm{~S}$ regulatory subunit [3]. This structure is a promising target for cancer therapy because it regulates the crucial process of proteasome-mediated protein degradation, which involves many proteins such as cyclins, caspases, Bcl-2 and the nuclear factor of $\kappa \mathrm{B}$ $(\mathrm{NF}-\kappa \mathrm{B})[2,4]$. Inhibiting proteasome activity leads to the accumulation of these proteins, resulting in cell cycle arrest and apoptosis. Bortezomib, a specific and selective

\footnotetext{
* Correspondence: drzhuhongbo@yahoo.com

'Department of Colorectal Surgery, Sir Run Run Shaw Hospital, School of

Medicine, Zhejiang University, Hangzhou, China

Full list of author information is available at the end of the article
}

inhibitor of $26 \mathrm{~S}$ proteasome, was approved for initial treatment of patients with Multiple Myeloma by the US Food and Drug Administration in 2008. Proteasome inhibitor-based combination therapies suggest that proteasome inhibitors could enhance chemosensitivity or reverse radiotherapy/chemotherapy resistance [5].

A growing body of evidence indicates that the intrinsic (or mitochondrial) apoptosis pathway represents a fundamental mechanism of apoptosis triggered by proteasome inhibition [6,7]. Indeed, the Bcl-2 family proteins, key activators of mitochondrial apoptosis, play a fundamental role in mediating proteasome inhibition-induced toxicity [8]. However, proteasome inhibitors not only increase the pro-apoptotic $\mathrm{Bcl}-2$ proteins [9-11], but they may also lead to the accumulation of anti-apoptotic Bcl-2 proteins [12]. These proteins include the Mcl-1

\section{Biomed Central}

(c) 2011 Zhou et al; licensee BioMed Central Ltd. This is an Open Access article distributed under the terms of the Creative Commons Attribution License (http://creativecommons.org/licenses/by/2.0), which permits unrestricted use, distribution, and reproduction in any medium, provided the original work is properly cited. 
anti-apoptotic protein, originally identified as an early induction gene during the differentiation of myeloid leukemia cells [13], which could block cytochrome c release from mitochondria by forming heterodimers with $\mathrm{BH}$ only proteins Bim and NOXA, or with Bak $[14,15]$. Thus, proteasome inhibitor-induced $\mathrm{Mcl}-1$ accumulation may negatively affect their cytotoxic activity. Targeting Mcl-1 might be a strategy for enhancing the anticancer effect of proteasome inhibitors [16].

Our previous study demonstrated that proteasome inhibitors would induced a rapid Bik accumulation in various cancer cells [17]. Bik was also a member of BH3-only proteins, so the question of whether there were elevated anti-apoptotic members of Bcl-2 family existing in our system emerged inevitably. To clarify this question, we analyzed the levels of several anti-apoptotic members of Bcl-2 family in different human cancer cell lines after they were treated with proteasome inhibitors. Our results demonstrated that proteasome inhibitors induced a rapid accumulation of Mcl-1 but not others in our cell lines. The possible underlying mechanism of this accumulation might be the stabilization of proteins from degradation. We also showed that the knockdown of Mcl-1 levels by RNA interference enhanced the apoptosis induced by proteasome inhibitors. These findings suggested that treatment with proteasome inhibitors could induce Mcl-1 accumulation in various cancer cells and that combining these inhibitors with Mcl-1 siRNA might be a more effective strategy for cancer therapy.

\section{Methods}

\section{Cells and cell culture}

Human colon cancer cell lines DLD1, LOVO, SW620, and HCT116; human lung cancer cell lines H1299; human ovarian cancer cell line SKOV3 which were owned by our lab and human breast cancer cell line MCF7 that was purchased from ATCC, were maintained in RPMI 1640 or Dulbecco's modified Eagle's medium supplemented with $10 \%(\mathrm{v} / \mathrm{v})$ heat-inactivated fetal bovine serum, $1 \%$ glutamine and $1 \times$ antibiotics-antimycotics mixture (Invitrogen, Carlsbad, CA, USA). All cells were cultured at $37^{\circ} \mathrm{C}$ in a humidified incubator containing $5 \% \mathrm{CO}_{2}$.

\section{Chemicals}

Bortezomib was obtained from the Pharmacy of Sir Run Run Shaw Hospital and dissolved in PBS at $5 \mathrm{mM}$ as a stock solution. Proteasome inhibitor MG132 and ALLN were purchased from Calbiochem (La Jolla, CA, USA) and diluted in DMSO at stock concentrations of 10 and $20 \mathrm{mM}$, respectively. Cycloheximide and DMSO were purchased from Sigma (St Louis, MO, USA). Mcl-1 siRNA and negative control siRNA were purchased from Santa Cruz Biotechnology (Santa Cruz, CA, USA). The transfection of siRNA was performed using Oligofectamine (Invitrogen, Carlsbad, CA, USA) according to the manufacturer's instructions.

\section{Western blot analysis}

Cells were lysed in Laemmli buffer after their respective treatments. Equal amounts of lysate were separated by $10 \%$ sodium dodecyl sulfate-polyacrylamide gel electrophoresis and evaluated by Western blot analysis as described previously [18]. Rabbit anti-human caspase-9, caspase-3, Bcl-2, Bcl-XL, and Mcl-1 antibodies were purchased from Santa Cruz Biotechnology (Santa Cruz, CA, USA). Mouse anti-human PARP antibodies were purchased from BD Pharmingen (San Diego, CA, USA). Mouse anti-human $\beta$-actin was obtained from Sigma.

\section{Cell viability assay}

The viability of the cell lines was determined by a sulforhodamine B colorimetric assay, as previously described [19]. Briefly, after fixation of adherent cells with trichloroacetic acid in a 96-well microplate, the protein was stained with sulforhodamine $B$, and the absorbance was determined at $570 \mathrm{~nm}$ to reflect the number of stained cells representing cell viability. The percentage of viable cells was determined relative to the cell viability of the PBS control, which was arbitrarily set as 1. Each experiment was performed in quadruplicate and repeated at least three times.

\section{Protein stability assay}

To determine protein stability, we treated cells with DMSO, MG132, bortezomib, or ALLN for up to $6 \mathrm{~h}$ and then added cycloheximide $(25 \mu \mathrm{g} / \mathrm{ml})$ to block protein synthesis [20]. Collected protein samples were subjected to Western blot analysis using anti-Mcl-1 antibody. Band densities were qualified using Optimas software (Media Cybernetics, Silver Spring, MD, USA), and the mean half-life of Mcl-1 was calculated.

\section{Flow cytometry assay}

Apoptosis was detected using an FITC Annexin-V Apoptosis Detection Kit (BD Pharmingen, San Diego, CA, USA) according to the manufacturer's instructions. The cells were digested with $0.25 \%$ trypsin, washed with cold phosphate-buffered saline (PBS) twice, and resuspended in binding buffer $\left(1 \times 10^{6}\right.$ cells $\left./ \mathrm{ml}\right)$. Then $100 \mu \mathrm{l}$ of the cell suspension $\left(1 \times 10^{5}\right.$ cells $)$ was incubated with $5 \mu \mathrm{l}$ of Annexin-V FITC and $5 \mu \mathrm{l}$ of propidium iodide (PI) for $15 \mathrm{~min}$ at room temperature in the dark. The population of apoptosis cells was analyzed by flow cytometry (BD FACSCalibur, Becton Dickinson, San Jose, CA, USA). 


\section{Statistical analysis}

The data were expressed as mean \pm SD. Differences among the treatment groups were assessed via ANOVA using statistical software (Statsoft, Tulsa, OK). A $P$-value of $\leq 0.05$ was considered significant. Survival was assessed using the Kaplan-Meier method.

\section{Results}

Rapid accumulation of $\mathrm{Mcl}-1$ induced by proteasome inhibitors in various cancer cells

In this study, we evaluated the effect of proteasome inhibitors on Mcl-1 protein expression. Firstly, Cell lines which were owned by our lab including human colon cancer cell lines DLD1, LOVO, SW620, HCT116, human ovarian cancer cell line SKOV3 and human lung cancer cell line H1299 were treated with different concentrations of bortezomib (0.1-5.0 $\mu \mathrm{M})$ for $6 \mathrm{~h}$. Proteins were then collected and subjected to Western blot assay. The results showed that Mcl-1 expression was rapidly and dramatically upregulated by bortezomib in all six cell lines (Figure 1A), even at $0.1 \mu \mathrm{M}$. However, bortezomib did not substantially alter the expression levels of Bcl-2 and Bcl-XL (Figure 1A). We observed similar results about $\mathrm{Mcl}-1$ when we used two other proteasome inhibitors, MG132 (Figure 1B) and calpain inhibitor I (ALLN) (Figure 1C). To evaluate whether the bortezomib could also induce Mcl-1 accumulation in other cancer cells besides the cell lines used as above, we chose the human breast cancer MCF7 cell line which was purchased from ATCC. However, Mcl-1 accumulation was not observed in this cell line (Figure 1D).

To investigate whether bortezomib treatment modifies Mcl-1 accumulation in cancer cells in a time-dependent manner, DLD1, LOVO and SKOV3 cells were treated with bortezomib $(1 \mu \mathrm{M})$ for 2-6 h. Western blot results demonstrated that in these cells, the bortezomibinduced Mcl-1 accumulation was time-dependent. Its accumulation started within $2 \mathrm{~h}$ after treatment and became much stronger over time. We observed similar results when we used two other proteasome inhibitors, MG132 and ALLN (Figure 2).

\section{Proteasome Inhibitors enhancement of $\mathrm{Mcl}-1$ protein stability}

Because proteasome inhibitors inhibit proteasomemediated protein degradation, proteasome inhibitormediated Mcl-1 accumulation is likely to be caused by stabilization of the protein. To test this hypothesis, we treated DLD1 cells with dimethylsulfoxide (DMSO), 1 $\mu \mathrm{M}$ bortezomib, $5 \mu \mathrm{M}$ MG132 or $20 \mu \mathrm{M}$ ALLN for $6 \mathrm{~h}$ and then added cycloheximide to block protein synthesis in DLD1 cells [20]. Cells were then harvested over time and Mcl-1 levels were assessed by Western blot. Mcl-1 protein was rapidly degraded in cells treated with DMSO (Figure 3A) and had a mean half-life of less than $1 \mathrm{~h}$. In contrast, in cells treated with bortezomib, MG132, or ALLN, the Mcl-1 protein level and mean half-life were stable, even after $6 \mathrm{~h}$ of cycloheximide treatment (Figure 3B). This result indicates that $\mathrm{Mcl}-1$ degradation was blocked by treatment with proteasome Inhibitors.

\section{Knockdown of Mcl-1 expression by siRNA enhanced MG132-induced cancer cell death}

Next, we studied the relationship between Mcl-1 accumulation and cells' susceptibility to proteasome inhibitors. Although the endogenous expression of $\mathrm{Mcl}-1$ varied, bortezomib induced the accumulation of $\mathrm{Mcl}-1$ in various cancer cells. The folds of Mcl-1 accumulation in these cell lines varied from 1.59 to 11.09 (Figure 4). Simultaneously, we also determined the susceptibility of these cells to the treatment of bortezomib. The result demonstrated that the sensitivity of cancer cells to bortezomib differed (Table 1 ). These results demonstrate that the cells' susceptibility to bortezomib was not obviously associated with the amount of Mcl-1 accumulation ( $\mathrm{r}=0.781, P=0.066)$.

In order to further determine the role of Mcl-1 accumulation during proteasome inhibitor treatment, we used siRNA to knock down the expression of Mcl-1 protein. For this purpose, DLD1 cells were treated with $50 \mathrm{nM} \mathrm{Mcl-1}$ or control siRNA for $24 \mathrm{~h}$; then, cells were treated with $1 \mu \mathrm{M}$ of MG132 for another $24 \mathrm{~h}$. Levels of Mcl-1 protein were determined by Western blot assay. In comparison with DMSO or control siRNA, pretreatment with Mcl-1 siRNA dramatically reduced Mcl-1 protein levels. Moreover, although treatment with MG132 still resulted in obvious Mcl-1 accumulation in cells pretreated with Mcl-1 siRNA, the level of this accumulation was dramatically lower than in cells pretreated by control siRNA (Figure 5A and 5B, $P$ $<0.01)$. This finding also suggests that MG132mediated Mcl-1 accumulation was extremely efficient and could occur when the Mcl-1 level was very low. Cell viability analysis showed that treatment with DMSO, control or Mcl-1 siRNA alone did not lead to cell viability loss. Treatment with MG132 for 24 h led to significant viability loss. However, in comparison with cells pretreated with control siRNA, pretreatment with Mcl-1 siRNA significantly enhanced MG132mediated cell death $(P<0.01$, Figure $5 C)$. A similar result was detected in the other colon cancer SW620 cell line $(P<0.01$, Figure $5 C)$. Thus, a reduced level of Mcl-1 accumulation correlates with increased cell death as a result of MG132. 


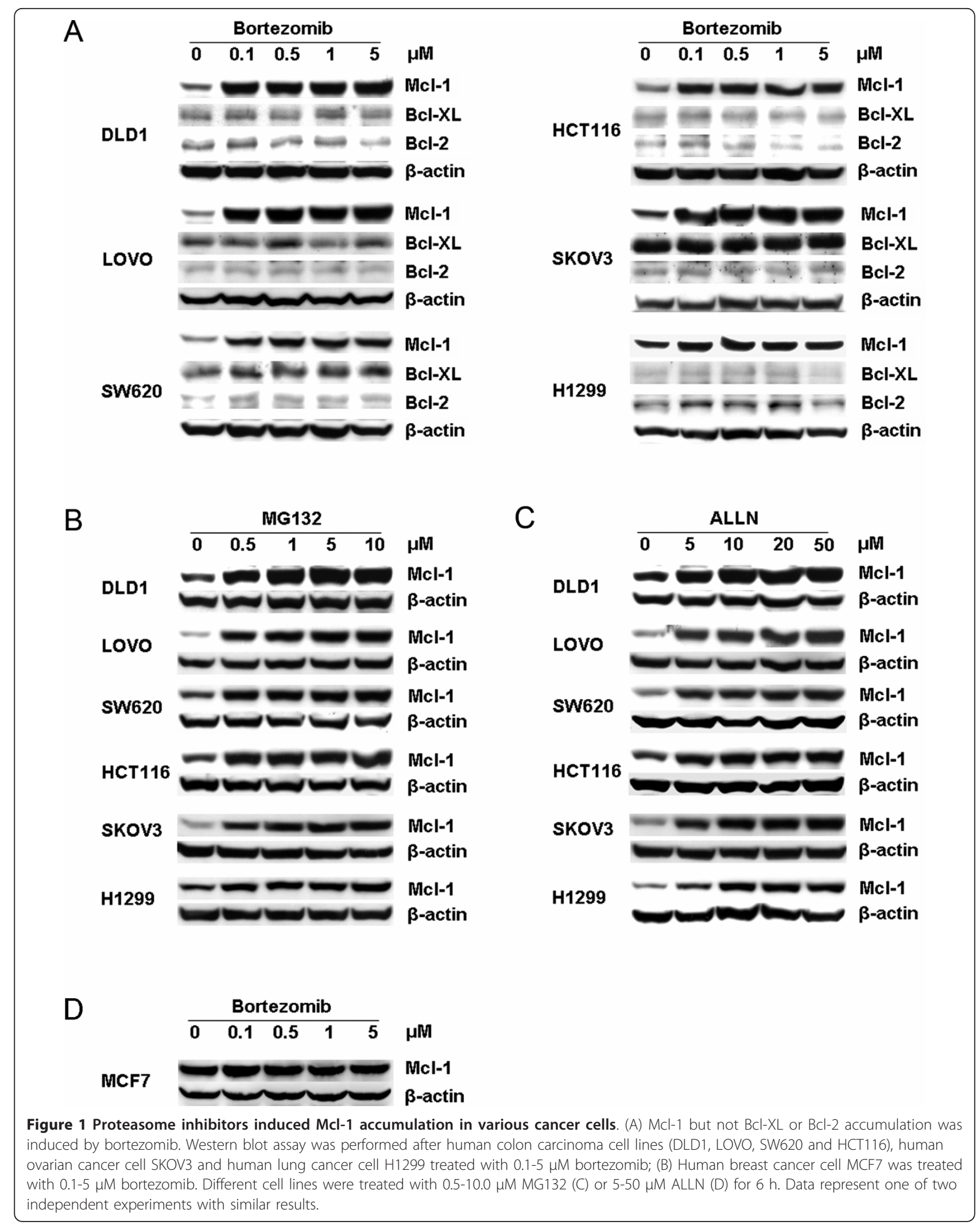




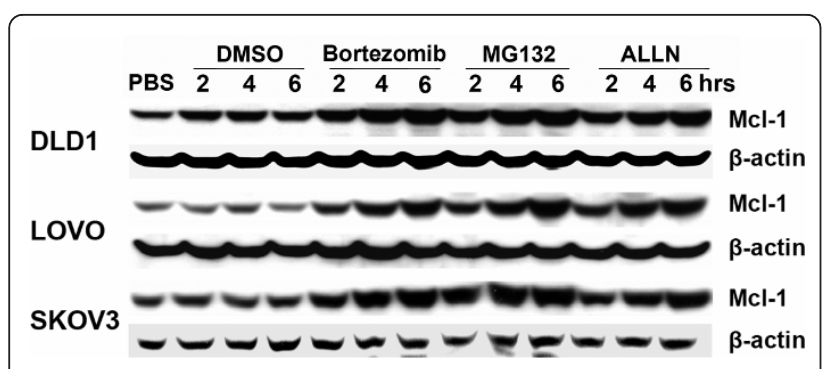

Figure 2 Western blot assay for Mcl-1 expression after treatment with proteasome inhibitors at different time points. DLD1, LOVO and SKOV3 cells were treated with $1 \mu \mathrm{M}$ bortezomib, 5 $\mu \mathrm{M}$ MG132 or $20 \mu \mathrm{M}$ ALLN for 2-6 h. Data represent one of two independent experiments with similar results.

\section{Mcl-1 siRNA enhanced MG132-induced apoptotic signaling}

Previous studies have shown that Mcl-1 is an anti-apoptotic protein that protects tumor cells against apoptosis. Thus, it is conceivable that the knockdown of Mcl-1 contributes to MG132-induced apoptosis. To confirm this hypothesis, DLD1 cells were treated with $\mathrm{Mcl}-1$ siRNA and MG132 as described above. Levels of apoptosis were determined by Annexin-V FITC/PI assay (Figure 6A). The results showed that treatment with Mcl-1 siRNA plus MG132 resulted in a significantly

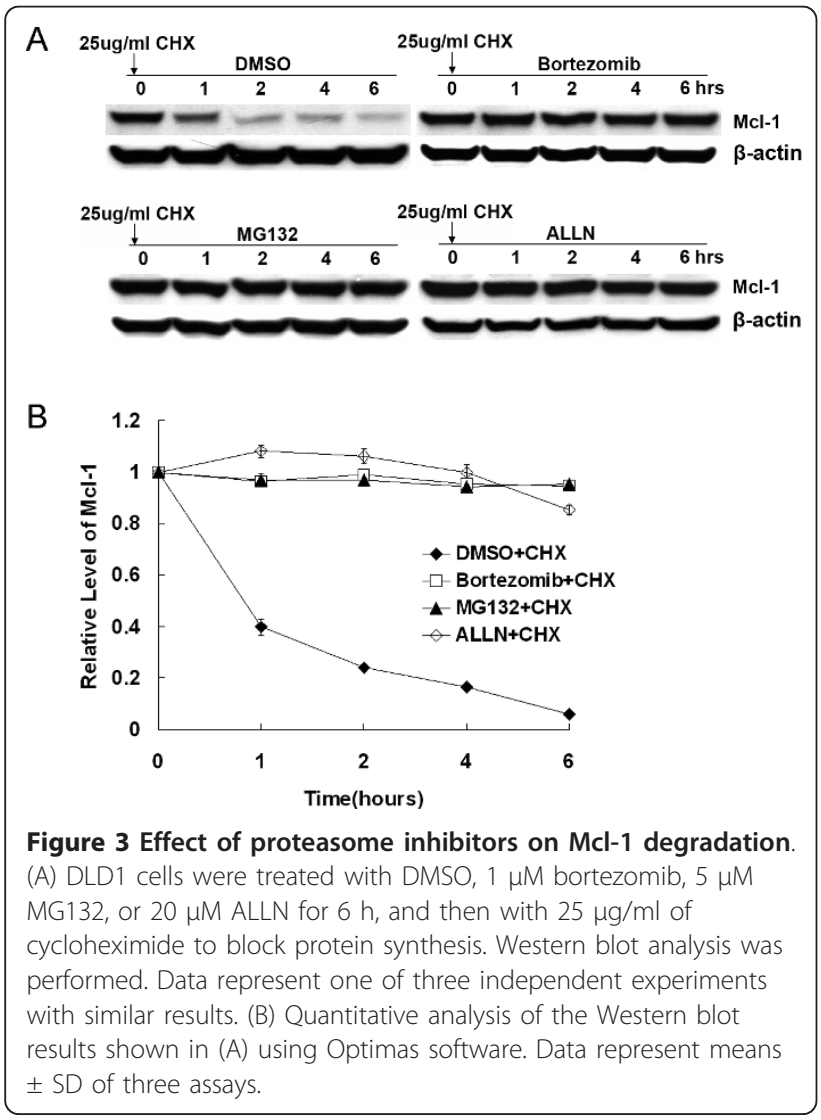

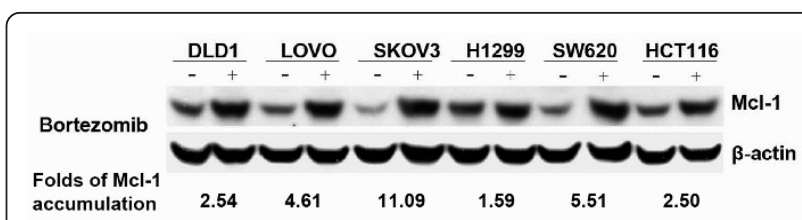

Figure 4 Bortezomib-induced Mcl-1 accumulation in different cancer cell lines. Cells were treated with $1 \mathrm{mM}$ bortezomib (+) for $6 \mathrm{~h}$ and harvested for Western blotting. Control cells (-) received no bortezomib. Data represent one of two independent experiments with similar results. Fold of Mcl-1 accumulation represents the value of accumulated $\mathrm{Mcl}-1$ normalized with its endogenous product.

higher apoptosis proportion $(22.07 \pm 3.44 \%)$ compared to control siRNA plus MG132 (12.22 $\pm 2.72 \%, P<0.01)$; whereas Mcl-1 (4.37 $\pm 0.43 \%)$ or control siRNA alone $(5.48 \pm 0.38 \%)$ was no more effective than the DMSO (3.94 $\pm 0.45 \%, P>0.05$, Figure 6B).

Furthermore, we simultaneously evaluated the cleavage of several molecular markers of mitochondrial apoptotic signaling, including caspase-9, caspase-3, and poly (ADP-ribose) polymerase (PARP), by Western blot in DLD1 cells. The results showed that in cells with a knockdown of Mcl-1, cleavage of caspase-9, caspase-3, and PARP was dramatically enhanced after treatment with MG132 compared with control siRNA-treated cells (Figure 6C). Mcl-1 downregulation by siRNA alone did not exhibit any detectable effects compared with control siRNA or DMSO.

\section{Discussion}

Proteasomes play an essential role in degrading or processing intracellular proteins, some of which mediate cell cycle progression and apoptosis. Previous studies have shown that many types of actively proliferating malignant cells are more sensitive to proteasome blockade than non-cancerous cells [2]. Therefore, proteasome inhibitors are thought to be a novel class of anticancer drugs.

Proteasome inhibitors have a documented activity in a number of hematologic malignancies, especially in multiple myeloma and mantle cell lymphoma [21,22]. However, despite encouraging preclinical data, studies in solid tumors have yielded disappointing results [23-25]. Even in the treatment of multiple myeloma, the majority of patients do not respond, and resistance is common. The mechanism of proteasome inhibitor resistance is undefined.

Bcl-2 family members play a fundamental role in the regulation of apoptosis and are substrates of the proteasome. Previous studies implicated a role in the accumulation of pro-apoptotic Bcl-2 family members in proteasome inhibitor-induced apoptosis [16,17]. Moreover, proteasome inhibitors may also upregulate the expression of antiapoptotic Bcl-2 family members [16]. 
Table 1 IC50 of Different Cell Lines after exposure to bortezomib

\begin{tabular}{ccccccc}
\hline & DLD1 & LOVO & SKOV3 & H1299 & SW620 & HCT116 \\
\hline bortezomib $(\mathrm{nM})$ & $22.5 \pm 2.62$ & $<10$ & $70.1 \pm 14.4$ & $25.6 \pm 3.1$ & $13.5 \pm 1.9$ & $17.7 \pm 1.2$ \\
\hline
\end{tabular}

We and others have reported that treatment with proteasome inhibitors does not affect the expression of Bcl2 and Bcl-XL $[10,17,26]$. However, Mcl-1 differs from $\mathrm{Bcl}-2$ and Bcl-XL because it is a short-lived molecule that is highly-regulated by ubiquitin proteasome pathway [16,27-29]. The ubiquitination of Mcl-1 is mediated by Mule-a BH3-only E3 ubiquitin ligase [30]. This process requires the association of Mcl-1 with Mule and is controlled by Noxa through the regulation of the $\mathrm{Mcl} /$ USP9X interaction [30-32]. The level of Mcl-1/Mule complex would determine the sensitivity of cancer cells to apoptosis [33]. Therefore, Mcl-1 is likely an important survival molecule for regulating proteasome inhibitor-induced apoptosis.

In this study, we report a significant upregulation of Mcl-1 in lung cancer cell line H1299, the ovarian cancer cell line SKOV3, and the colon cancer cell lines DLD-1, LOVO, SW620 and HCT116 after treatment with different proteasome inhibitors. This effect is likely due to prolong half-life of Mcl-1. These results are similar with other previous studies, which showed that proteasome inhibitors upregulated Mcl-1 protein expression in melanoma and myeloma [16,26,34]. Previously, we had reported that proteasome inhibitors could induce Bik accumulation in various cancer cells [17]. Here we further reported that proteasome inhibitors could also induce Mcl-1 accumulation in these cells. Although both Bik and Mcl-1 protein were accumulated in these cells, they should play distinct role for cell survival. We had demonstrated that Bik accumulation induced by proteasome inhibitors might play a pro-apoptotic role in these cells [17]. Meanwhile, it had been reported that

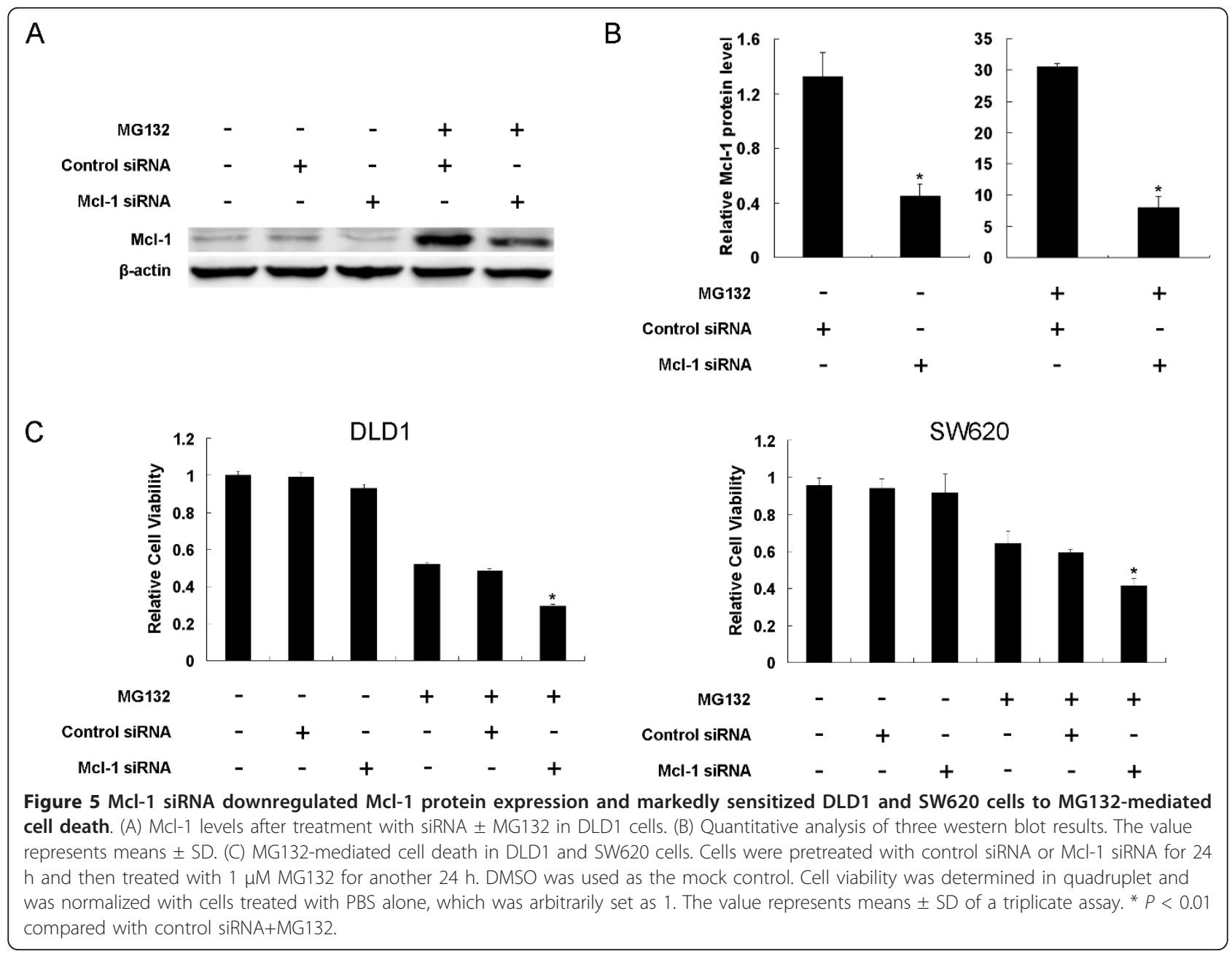




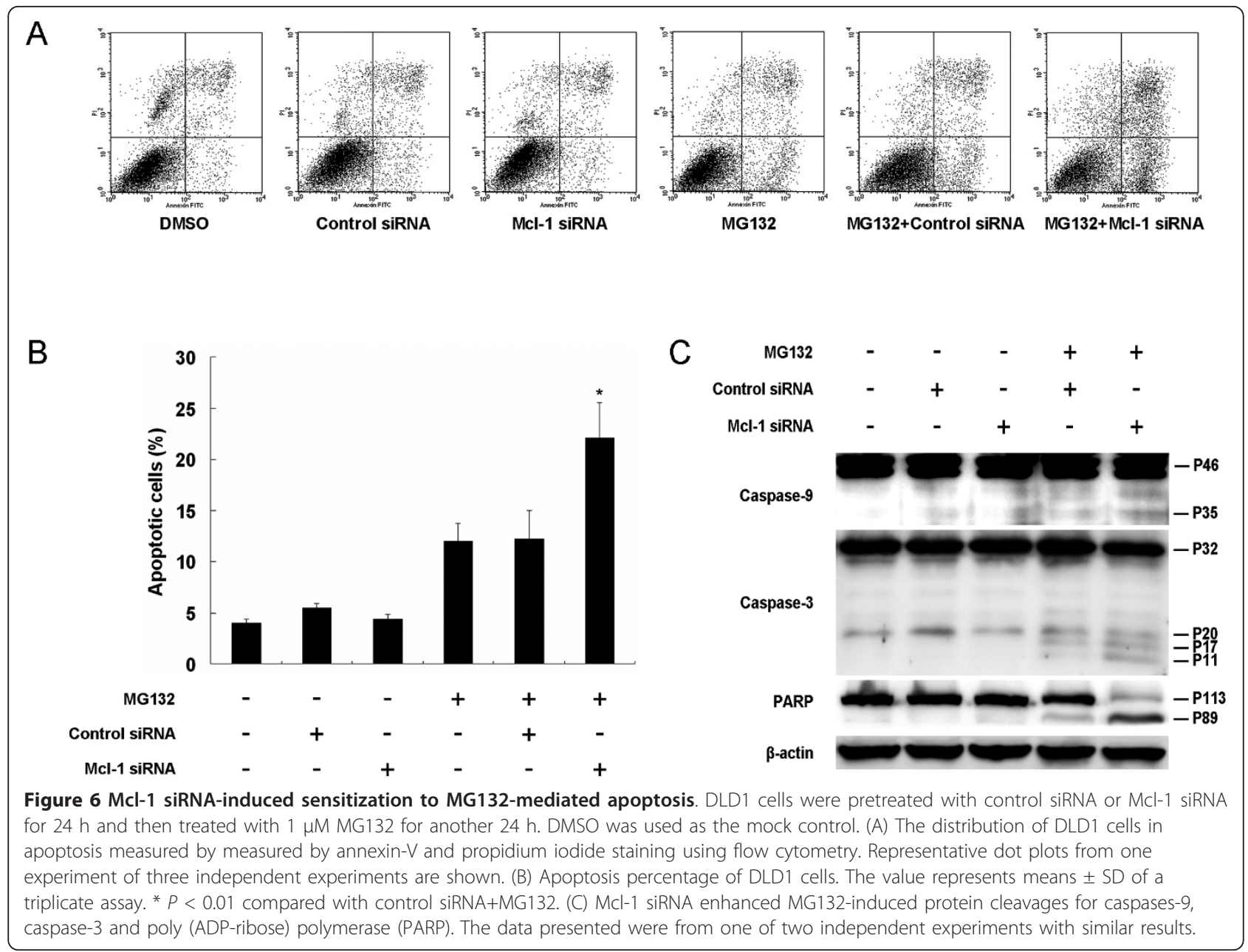

overexpressed Mcl-1 help malignant cells resistance to proteasome inhibitors [16]. Therefore, proteasome inhibitors-induced Mcl-1 in our cells may also interfere with its therapeutic effect $[11,35]$.

To further explore the role of Mcl-1 after treatment with proteasome inhibitor, we used RNA interference to knockdown Mcl-1 levels in DLD1 cells. Our results demonstrated that although the absolute value of difference between control siRNA+MG132 group and Mcl1siRNA+MG132 group is not so large, $\mathrm{Mcl}-1$ siRNA significantly increased the cytotoxicity of proteasome inhibitors $(P<0.01)$. Our data were consistent with studies on other tumor types, such as melanoma, myeloma and malignant pleural mesothelioma, in which the specific downregulation of $\mathrm{Mcl}-1$ has been shown to sensitize cancer cells to proteasome inhibitor-induced apoptosis $[16,35,36]$. These data suggested that Mcl-1 could partial prevent cells from death. Base on these, we don't think that Mcl-1 increase following proteasome inhibitors treatment is an epiphenomenon without a functional meaning. These results also provide a molecular basis for a rational combination of proteasome inhibitors with a Mcl-1 antagonist, such as siRNA, UV light, or fludarabine $[12,16]$. In the case of a potent cytotoxic with a restrictive side-effect profile [37], such as bortezomib, this combination strategy may also be effective using lower drug concentrations to avoid or minimize toxicities. Previous reports have shown that the knockdown of Mcl-1 significantly induced spontaneous apoptosis by its own $[38,39]$. However, we did not find obvious cell death or apoptosis after the specific downregulation of Mcl-1 in DLD1 cells, suggesting that merely losing Mcl1 expression may not be enough to induce apoptosis. The explanation for the differential effects of Mcl-1 knockdown on the survival of different cells is not entirely clear but might reflect different expression levels of other Bcl-2 family proteins related to Mcl-1 [14].

\section{Conclusions}

Our data showed that proteasome inhibitors induced not only Bik but also Mcl-1 accumulation in several cancer cell lines, particularly human colon cancer cell 
lines, and that this accumulation was mainly due to the stabilization of the Mcl-1 protein by proteasome inhibitors. The downregulation of Mcl-1 by Mcl-1 siRNA enhanced the apoptosis induced by proteasome inhibitors. Thus, using combined treatment with proteasome inhibitors and Mcl-1 antagonists may provide an effective and safe strategy for cancer therapy.

\section{Acknowledgements}

This work was supported by grants from the National Natural Science Foundation of China (30700970) and the Fundamental Research Funds for the Central Universities.

\section{Author details}

${ }^{1}$ Department of Colorectal Surgery, Sir Run Run Shaw Hospital, School of Medicine, Zhejiang University, Hangzhou, China. ${ }^{2}$ Key Laboratory of Biotherapy of Zhejiang province, Hangzhou, China. ${ }^{3}$ Department of Internal Medicine, Aviation Medical Evaluation \& Training center of Airforce in Hangzhou, Hangzhou, China.

\section{Authors' contributions}

WZ performed experimental and statistical analysis and drafted the manuscript. JZH and HMT participated in flow cytometry and SRB assay. DW participated in Western blot analysis. XFH and $\mathrm{CH}$ participated in manuscript proofreading. HBZ conceived the design, provided financial support, participated Western blot analysis and revised the manuscript. All authors read and approved the final manuscript.

\section{Competing interests}

The authors declare that they have no competing interests.

Received: 4 July 2011 Accepted: 14 November 2011

Published: 14 November 2011

\section{References}

1. Adams J: The development of proteasome inhibitors as anticancer drugs. Cancer Cell 2004, 5(5):417-421.

2. Adams J: The proteasome: a suitable antineoplastic target. Nat Rev Cancer 2004, 4(5):349-360.

3. Nussbaum AK, Dick TP, Keilholz W, Schirle M, Stevanovic S, Dietz K, Heinemeyer W, Groll M, Wolf DH, Huber R, et al: Cleavage motifs of the yeast $20 \mathrm{~S}$ proteasome beta subunits deduced from digests of enolase 1. Proc Natl Acad Sci USA 1998, 95(21):12504-12509.

4. Karin M, Yamamoto $Y$, Wang QM: The IKK NF-kappa B system: a treasure trove for drug development. Nat Rev Drug Discov 2004, 3(1):17-26.

5. Orlowski RZ, Kuhn DJ: Proteasome inhibitors in cancer therapy: lessons from the first decade. Clin Cancer Res 2008, 14(6):1649-1657.

6. Voortman J, Checinska A, Giaccone G, Rodriguez JA, Kruyt FA: Bortezomib, but not cisplatin, induces mitochondria-dependent apoptosis accompanied by up-regulation of noxa in the non-small cell lung cancer cell line NCl-H460. Mol Cancer Ther 2007, 6(3):1046-1053.

7. Yuan BZ, Chapman J, Reynolds SH: Proteasome inhibitors induce apoptosis in human lung cancer cells through a positive feedback mechanism and the subsequent Mcl-1 protein cleavage. Oncogene 2009, 28(43):3775-3786.

8. Fennell DA, Chacko A, Mutti L: BCL-2 family regulation by the $20 \mathrm{~S}$ proteasome inhibitor bortezomib. Oncogene 2008, 27(9):1189-1197.

9. $Y u$ J, Tiwari $S$, Steiner $P$, Zhang L: Differential apoptotic response to the proteasome inhibitor Bortezomib [VELCADE, PS-341] in Bax-deficient and p21-deficient colon cancer cells. Cancer Biol Ther 2003, 2(6):694-699.

10. Nikrad M, Johnson T, Puthalalath H, Coultas L, Adams J, Kraft AS: The proteasome inhibitor bortezomib sensitizes cells to killing by death receptor ligand TRAIL via BH3-only proteins Bik and Bim. Mol Cancer Ther 2005, 4(3):443-449.

11. Perez-Galan P, Roue G, Villamor N, Montserrat E, Campo E, Colomer D: The proteasome inhibitor bortezomib induces apoptosis in mantle-cell lymphoma through generation of ROS and Noxa activation independent of p53 status. Blood 2006, 107(1):257-264.
12. Nijhawan D, Fang M, Traer E, Zhong Q, Gao W, Du F, Wang X: Elimination of $\mathrm{Mcl}-1$ is required for the initiation of apoptosis following ultraviolet irradiation. Genes Dev 2003, 17(12):1475-1486.

13. Kozopas KM, Yang T, Buchan HL, Zhou P, Craig RW: MCL1, a gene expressed in programmed myeloid cell differentiation, has sequence similarity to BCL2. Proc Natl Acad Sci USA 1993, 90(8):3516-3520.

14. Adams KW, Cooper GM: Rapid turnover of mcl-1 couples translation to cell survival and apoptosis. J Biol Chem 2007, 282(9):6192-6200.

15. Chen L, Willis SN, Wei A, Smith BJ, Fletcher Jl, Hinds MG, Colman PM, Day $\mathrm{CL}$, Adams JM, Huang DC: Differential targeting of prosurvival $\mathrm{BCl}-2$ proteins by their $\mathrm{BH} 3$-only ligands allows complementary apoptotic function. Mol Cell 2005, 17(3):393-403.

16. Qin JZ, Xin H, Sitailo LA, Denning MF, Nickoloff BJ: Enhanced killing of melanoma cells by simultaneously targeting $\mathrm{Mcl}-1$ and NOXA. Cancer Res 2006, 66(19):9636-9645.

17. Zhu H, Zhang L, Dong F, Guo W, Wu S, Teraishi F, Davis JJ, Chiao PJ, Fang B: Bik/NBK accumulation correlates with apoptosis-induction by bortezomib (PS-341, Velcade) and other proteasome inhibitors. Oncogene 2005, 24(31):4993-4999.

18. Wu S, Zhu H, Gu J, Zhang L, Teraishi F, Davis JJ, Jacob DA, Fang B: Induction of apoptosis and down-regulation of $\mathrm{BCl}-\mathrm{XL}$ in cancer cells by a novel small molecule, 2[[3-(2, 3-dichlorophenoxy)propyl]amino] ethanol. Cancer Res 2004, 64(3):1110-1113.

19. Pauwels B, Korst AE, de Pooter CM, Pattyn GG, Lambrechts HA, Baay MF, Lardon F, Vermorken JB: Comparison of the sulforhodamine B assay and the clonogenic assay for in vitro chemoradiation studies. Cancer Chemother Pharmacol 2003, 51(3):221-226.

20. Kim GY, Mercer SE, Ewton DZ, Yan Z, Jin K, Friedman E: The stressactivated protein kinases p38 alpha and JNK1 stabilize p21(Cip1) by phosphorylation. J Biol Chem 2002, 277(33):29792-29802.

21. San Miguel JF, Schlag R, Khuageva NK, Dimopoulos MA, Shpilberg O, Kropff M, Spicka I, Petrucci MT, Palumbo A, Samoilova OS, et al: Bortezomib plus melphalan and prednisone for initial treatment of multiple myeloma. N Engl J Med 2008, 359(9):906-917.

22. Kane RC, Dagher R, Farrell A, Ko CW, Sridhara R, Justice R, Pazdur R: Bortezomib for the treatment of mantle cell lymphoma. Clin Cancer Res 2007, 13(18 Pt 1):5291-5294.

23. Markovic SN, Geyer SM, Dawkins F, Sharfman W, Albertini M, Maples W, Fracasso PM, Fitch T, Lorusso P, Adjei AA, et al: A phase II study of bortezomib in the treatment of metastatic malignant melanoma. Cancer 2005, 103(12):2584-2589.

24. Kondagunta GV, Drucker B, Schwartz L, Bacik J, Marion S, Russo P, Mazumdar M, Motzer RJ: Phase II trial of bortezomib for patients with advanced renal cell carcinoma. J Clin Oncol 2004, 22(18):3720-3725.

25. Kozuch PS, Rocha-Lima CM, Dragovich T, Hochster H, O'Neil BH, Atiq OT, Pipas JM, Ryan DP, Lenz HJ: Bortezomib with or without irinotecan in relapsed or refractory colorectal cancer: results from a randomized phase II study. J Clin Oncol 2008, 26(14):2320-2326.

26. Nencioni A, Hua F, Dillon CP, Yokoo R, Scheiermann C, Cardone MH, Barbieri E, Rocco I, Garuti A, Wesselborg S, et al: Evidence for a protective role of $\mathrm{Mcl}-1$ in proteasome inhibitor-induced apoptosis. Blood 2005, 105(8):3255-3262.

27. Opferman JT, Letai A, Beard C, Sorcinelli MD, Ong CC, Korsmeyer SJ: Development and maintenance of $B$ and $T$ lymphocytes requires antiapoptotic MCL-1. Nature 2003, 426(6967):671-676.

28. Herrant $M$, Jacquel A, Marchetti S, Belhacene N, Colosetti P, Luciano F, Auberger $\mathrm{P}$ : Cleavage of $\mathrm{Mcl}-1$ by caspases impaired its ability to counteract Bim-induced apoptosis. Oncogene 2004, 23(47):7863-7873.

29. Derouet M, Thomas L, Cross A, Moots RJ, Edwards SW: Granulocyte macrophage colony-stimulating factor signaling and proteasome inhibition delay neutrophil apoptosis by increasing the stability of Mcl-1. $\mathrm{J}$ Biol Chem 2004, 279(26):26915-26921.

30. Zhong Q, Gao W, Du F, Wang X: Mule/ARF-BP1, a BH3-only E3 ubiquitin ligase, catalyzes the polyubiquitination of $\mathrm{MCl}-1$ and regulates apoptosis. Cell 2005, 121(7):1085-95.

31. Warr MR, Acoca S, Liu Z, Germain M, Watson M, Blanchette M, Wing SS, Shore GC: BH3-ligand regulates access of MCL-1 to its E3 ligase. FEBS Lett 2005, 579(25):5603-8.

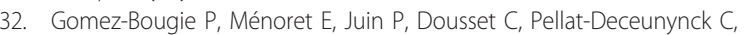
Amiot M: Noxa controls Mule-dependent Mcl-1 ubiquitination through 
the regulation of the Mcl-1/USP9X interaction. Biochem Biophys Res Commun 2011.

33. Pervin S, Tran A, Tran L, Urman R, Braga M, Chaudhuri G, Singh R: Reduced association of anti-apoptotic protein Mcl-1 with E3 ligase Mule increases the stability of Mcl-1 in breast cancer cells. Br J Cancer 2011, 105(3):428-37.

34. Qin JZ, Ziffra J, Stennett L, Bodner B, Bonish BK, Chaturvedi V, Bennett F, Pollock PM, Trent JM, Hendrix MJ, et al: Proteasome inhibitors trigger NOXA-mediated apoptosis in melanoma and myeloma cells. Cancer Res 2005, 65(14):6282-6293.

35. Gomez-Bougie P, Wuilleme-Toumi S, Menoret E, Trichet V, Robillard N, Philippe M, Bataille R, Amiot M: Noxa up-regulation and Mcl-1 cleavage are associated to apoptosis induction by bortezomib in multiple myeloma. Cancer Res 2007, 67(11):5418-5424.

36. Yuan BZ, Chapman JA, Reynolds SH: Proteasome Inhibitor MG132 Induces Apoptosis and Inhibits Invasion of Human Malignant Pleural Mesothelioma Cells. Transl Oncol 2008, 1(3):129-140.

37. Caravita T, de FP, Palumbo A, Amadori S, Boccadoro M: Bortezomib: efficacy comparisons in solid tumors and hematologic malignancies. Nat Clin Pract Oncol 2006, 3(7):374-387.

38. Chetoui N, Sylla K, Gagnon-Houde JV, caide-Loridan C, Charron D, AlDaccak R, Aoudjit F: Down-regulation of $m c-1$ by small interfering RNA sensitizes resistant melanoma cells to fas-mediated apoptosis. Mol Cancer Res 2008, 6(1):42-52.

39. Zhang B, Gojo I, Fenton RG: Myeloid cell factor-1 is a critical survival factor for multiple myeloma. Blood 2002, 99(6):1885-1893.

\section{Pre-publication history}

The pre-publication history for this paper can be accessed here: http://www.biomedcentral.com/1471-2407/11/485/prepub

doi:10.1186/1471-2407-11-485

Cite this article as: Zhou et al:: Small interfering RNA targeting mcl-1 enhances proteasome inhibitor-induced apoptosis in various solid malignant tumors. BMC Cancer 2011 11:485.

\section{Submit your next manuscript to BioMed Central} and take full advantage of:

- Convenient online submission

- Thorough peer review

- No space constraints or color figure charges

- Immediate publication on acceptance

- Inclusion in PubMed, CAS, Scopus and Google Scholar

- Research which is freely available for redistribution

Submit your manuscript at www.biomedcentral.com/submit
Biomed Central 